\title{
Complex genetic structure revealed in the circum-Antarctic broadcast spawning sea urchin Sterechinus neumayeri
}

\author{
Karen J. Miller ${ }^{1, *}$, Helena P. Baird ${ }^{2}$, Jake van Oosterom ${ }^{3}$, Julie Mondon ${ }^{3}$, \\ Catherine K. King ${ }^{2}$ \\ ${ }^{1}$ Australian Institute of Marine Science, UWA Oceans Institute, 35 Stirling Highway, Crawley, WA 6009, Australia \\ ${ }^{2}$ Australian Antarctic Division, 203 Channel Highway, Kingston, TAS 7050, Australia \\ ${ }^{3}$ Centre for Integrative Ecology, School of Life and Environmental Sciences, Deakin University, Geelong, VIC 3216, Australia
}

\begin{abstract}
Patterns and mechanisms of gene flow and larval dispersal in the Antarctic marine environment are still poorly understood, despite the current threat of rapid climate change and the need for such information to inform conservation and management efforts. Studies on Antarctic brooding marine invertebrates have demonstrated limited connectivity, concurrent with life history expectations; however, no equivalent data are available for broadcast spawning species for which we might expect a higher capacity for larval dispersal. Here, we have used microsatellite DNA markers and mitochondrial DNA sequence data to explore patterns of genetic structure and infer larval dispersal patterns across spatial scales of $<500 \mathrm{~m}$ to $1400 \mathrm{~km}$ in the broadcast spawning sea urchin Sterechinus neumayeri. We show genetic differentiation at small spatial scales $(<1 \mathrm{~km})$, but genetic homogeneity over moderate $(1-25 \mathrm{~km})$ and large spatial scales $(1000 \mathrm{~km})$, consistent with patterns described as chaotic genetic patchiness. Self-recruitment appears common in $S$. neumayeri, and genotypes of larvae collected from the water column provide preliminary evidence that the adult population structure is maintained through variability among larval cohorts. Genetic similarity at large spatial scales may represent evolutionary connectivity on a circum-Antarctic scale, and likely also reflects a history of shelf recolonisation after isolation in glacial refugia.
\end{abstract}

KEY WORDS: Gene flow - Larval dispersal - Migration - Chaotic genetic patchiness . Microsatellites $\cdot$ Echinoid

\section{INTRODUCTION}

Gene flow in the marine environment underpins the maintenance of genetic diversity and resilience to change, and has long been considered to reflect the dispersal potential determined by life history characteristics (Roberts 1997, Faurby \& Barber 2012). Indeed, there is much empirical evidence supporting a correlation between the length of a pelagic larval phase and the extent of genetic exchange between populations. Direct-developing lecithotrophic and brooding species generally display high genetic

\footnotetext{
*Corresponding author: k.miller@aims.gov.au
}

structure, while planktotrophic species with longlived planktonic embryonic and larval phases achieve genetic homogeneity over large scales (see Hunt 1993, Teske et al. 2007, Underwood et al. 2009, Haye et al. 2014, Weber et al. 2015 for comparisons). However, studies that contradict this rule abound, and a paradigm shift is gaining momentum. In particular, broadcast-spawning species with long pelagic larval phases often show surprising levels of genetic differentiation over small spatial scales (e.g. Taylor \& Hellberg 2003, Miller et al. 2009, Sá-Pinto et al. 2012, Penant et al. 2013).

(C) The authors 2018. Open Access under Creative Commons by Attribution Licence. Use, distribution and reproduction are unrestricted. Authors and original publication must be credited. 
Several factors have been identified that may limit gene flow in benthic marine species with long pelagic larval phases and high dispersal potential. Larval retention, localised adaptation, dispersal barriers such as abyssal depths and convergence zones, and the timing of reproductive events can all isolate populations (Reeb \& Avise 1990, Palumbi 1994, Lessios et al. 1999, McCartney et al. 2000, Hunter \& Halanych 2008, 2010, Miller \& Ayre 2008, Thornhill et al. 2008, Calderon \& Turon 2010, Kelly \& Palumbi 2010, Maltagliati et al. 2010, Hoffman et al. 2011, $\mathrm{Ni}$ et al. 2011). However, an increasing number of broadcast-spawning species are found to be genetically differentiated at the smallest spatial scale studied, with apparent connectivity over larger scales (e.g. Hedgecock 1994, Hogan et al. 2010, Larson \& Julian 1999). Such patterns, referred to as chaotic genetic patchiness (Johnson \& Black 1982), prove challenging to explain, yet are likely to be found frequently as more studies focus at a fine spatial resolution (e.g. Arnaud-Haond et al. 2008, Miller et al. 2009).

Chaotic genetic patchiness encompasses the capacity for larval dispersal to homogenise populations over large scales, while temporal and spatial variation in the availability and genetic composition of larvae may still result in fine-scale genetic structure (Johnson \& Black 1982). Several pre-settlement mechanisms have been hypothesised to drive this variation in larval recruits (see Hogan et al. 2010). These include localised natural selection acting on larval cohorts, 'sweepstake reproductive success' (variability in reproductive success of source populations), and collective dispersal of larval cohorts from spatially/temporally distinct source populations. Sweepstake reproductive success has perhaps received the most attention (Hedgecock 1982, Hedgecock \& Pudovkin 2011) and predicts that large variances in reproductive success occur due to 'sweepstakes' where only a small number of individuals synchronise reproduction with optimal oceanographic conditions necessary for successful recruitment. This results in a reduction in effective population size; and is accompanied by reduced genetic diversity in larval cohorts compared to adult populations (Hedgecock 1994, Hedgecock \& Pudovkin 2011). Most processes leading to chaotic genetic patchiness are contingent upon the persistence of cohesive, genetically differentiated cohorts of larvae remaining aggregated in the water column. There is only limited empirical evidence of this to date (Johnson et al. 1993, Riquet et al. 2017) as planktonic larvae are notoriously difficult to collect, and more studies of larval genetic structure are needed (Broquet et al. 2013).

The vast majority of research on larval dispersal and genetic connectivity patterns has focused on temperate and tropical species (Hess et al. 1988, McCartney et al. 2000, Lessios et al. 2001, Addison \& Hart 2004, Duran et al. 2004, Waters \& Roy 2004, Banks et al. 2007, Yasuda et al. 2009, Kelly \& Palumbi 2010, Maltagliati et al. 2010). Despite being under greater immediate threat from environmental change (Peck 2005), Antarctic benthic fauna remain much less understood in this respect. The nature of Antarctic waters provides unique conditions that may influence genetic structure: extremely low and stable temperatures, a coastline spanning only a few degrees of latitude, and the presence of strong circumpolar currents. In combination, these factors might be expected to homogenise populations; however, the history of glacial cycles that have drastically reduced available benthic habitat may have isolated populations and reduced genetic diversity. That very few studies of fine-scale genetic structure exist for Antarctic marine invertebrates limits our capacity to incorporate small-scale patterns in management and planning (Féral 2002, Palumbi 2003, Palsbøll et al. 2007). Of the few studies that do exist, most focus on brooding species, which have no larval stage and therefore very low dispersal potential, and, unsurprisingly, show evidence of fine genetic structure (Hunter \& Halanych 2010, Arango et al. 2011, Baird et al. 2012, Ledoux et al. 2012). Studies of broadcastspawning Antarctic benthic invertebrates with planktonic larvae have mainly focused on large-scale connectivity across major oceanographic barriers (e.g. Thornhill et al. 2008). To our knowledge, only a single study has identified fine-scale population structure in a broadcast-spawning Antarctic benthic invertebrate, the mollusc Nacella concinna; however, the drivers of this structure remain unknown (Hoffman et al. 2012).

The Antarctic echinoid Sterechinus neumayeri is an ideal organism for testing the predictions of life history characteristics on population genetic structure in an Antarctic benthic marine broadcast spawner. This species is an abundant and dominant component of the nearshore benthos, with a circum-Antarctic distribution (Brey et al. 1995, Sahade et al. 1998), and is well studied with regards to its environmental sensitivities (e.g. King \& Riddle 2001, Lister et al. 2010, Ericson et al. 2012, Byrne et al. 2013, Lister et al. 2015, Foo et al. 2016). It reproduces annually during the austral summer from November to December (Pearse et al. 1991), and larvae spend approximately 4 mo in 
the water column before metamorphosis and settlement (Bosch et al. 1987, Brey et al. 1995). This extended larval stage and development time likely reflects their reduced metabolic rate in cold waters, as well as providing a strategy for planktotrophic larvae to exploit the highly seasonal planktonic food sources of Antarctic waters (Bosch et al. 1987, Brey et al. 1995, Brockington et al. 2007). The larval phase of $S$. neumayeri confers a high dispersal potential compared to related broadcast-spawning temperate and tropical echinoids, in which larvae remain in the water column for only days or weeks. In addition, the presence of the Antarctic Circumpolar Current (ACC) potentially provides a mechanism for westward offshore larval transport, which encompasses the entire continent (Nowlin \& Klinck 1986). Previous studies at the phylogenetic level based on mitochondrial DNA suggest that $S$. neumayeri may sustain considerable connectivity on a circum-Antarctic scale (Díaz et al. 2011), yet have reduced genetic diversity due to historical population reductions during glacial cycles (González-Wevar et al. 2012).

In the present study, we used microsatellite and mitochondrial DNA markers to provide a comprehensive analysis of genetic structure and connectivity at small and large scales in $S$. neumayeri from East Antarctica. Additionally, we determined genetic structure of larval cohorts to explore the potential role of chaotic genetic patchiness in structuring Antarctic benthic communities.

\section{MATERIALS AND METHODS}

\section{Sample collection}

Samples of adult Sterechinus neumayeri were collected in East Antarctica during the 2008/2009 summer field season at Casey station in the Windmill Islands $\left(66^{\circ} \mathrm{S}, 110^{\circ} \mathrm{E}\right)$ and the $2009 / 2010$ summer field season at Davis station in the Vestfold Hills $\left(68^{\circ} \mathrm{S}, 78^{\circ} \mathrm{E}\right.$; Fig. 1). In order to partition microsatellite variation into different spatial scales to infer patterns of larval dispersal, a hierarchical sampling design was used. Region represented the largest spatial scale, between the Windmill Islands and Vestfold Hills, which are separated by approximately $1400 \mathrm{~km}$. Sampling within the Windmill Islands was from 2 locations $9 \mathrm{~km}$ apart and within the Vestfold Hills from 5 locations separated by 5-30 km (Fig. 1). Within each location, 25-50 individuals were collected from up to 3 sites approximately $500 \mathrm{~m}$ apart, by dip netting, snorkeling, or surface-supply divers, and were returned live to the laboratory for processing. All individuals were considered mature based on the presence of sperm or eggs in gonad tissue, and were $4-16 \mathrm{~cm}$ in test diameter. A small sample of gonad tissue was dissected from each individual and stored in $95 \%$ ethanol for DNA extraction and genetic analysis.

Echinoplutei larvae were collected from plankton tows in the Vestfold Hills region during the 2009/ 2010 summer field season at 2 sampling locations approximately $1 \mathrm{~km}$ apart (Fig. 1). Larvae were collected from 3 plankton tows: 2 conducted near Kazak Island on 4 February 2010 and 8 February 2010, and 1 near Hawker Island on 9 February 2010 (Fig. 1); additional plankton tows in the region yielded no echinoplutei. All tows were carried out within $0.5 \mathrm{~m}$ of the water's surface, and were continued for 20-50 m, using a $200 \mu \mathrm{m}$ mesh net with a circular opening of $0.5 \mathrm{~m}$ and a $500 \mathrm{ml}$ cod end. Plankton that accumulated in the cod end and on the internal net surface was rinsed into a collection jar. Samples were fixed with $95 \%$ ethanol and sorted under a dissecting microscope $(10 \times)$. As $S$. neumayeri is the only species of regular echinoid found in shallow nearshore waters of Antarctica (Dell et al. 1972), all echinoplutei larvae found in samples were assumed to be $S$. neumayeri and were removed and stored individually in $95 \%$ ethanol. All larvae collected were 4 - to 8-armed pluteus stages, with estimated age between 40 and $100 \mathrm{~d}$, and likely to have spent 1-3 mo dispersing in the water column prior to collection.

\section{DNA extraction and genotyping}

DNA was extracted from gonad tissue using Qiagen DNeasy Blood and Tissue extraction kits following the manufacturer's protocols. Larval DNA extractions were performed using whole echinoplutei and Qiagen QIAamp DNA Micro extraction kits as per the manufacturer's protocol. Genomic DNA was quantified using a Nanodrop 8000 Spectrophotometer (Thermo Scientific).

To assess genetic patterns at the regional scale (i.e. between the Windmill Islands and Vestfold Hills), we sequenced the mitochondrial gene regions cytochrome oxidase sub-unit 1 (CO1) and ribosomal subunit $16 \mathrm{~S}$ from a sub-set of the adult samples from each region using urchin-specific primers and universal primers, respectively (Table S1 in the supplement at www-int-res.com/articles/suppl/m601p153_ supp.pdf). Bidirectional sequencing was performed by the Australian Genome Research Facility (Bris- 


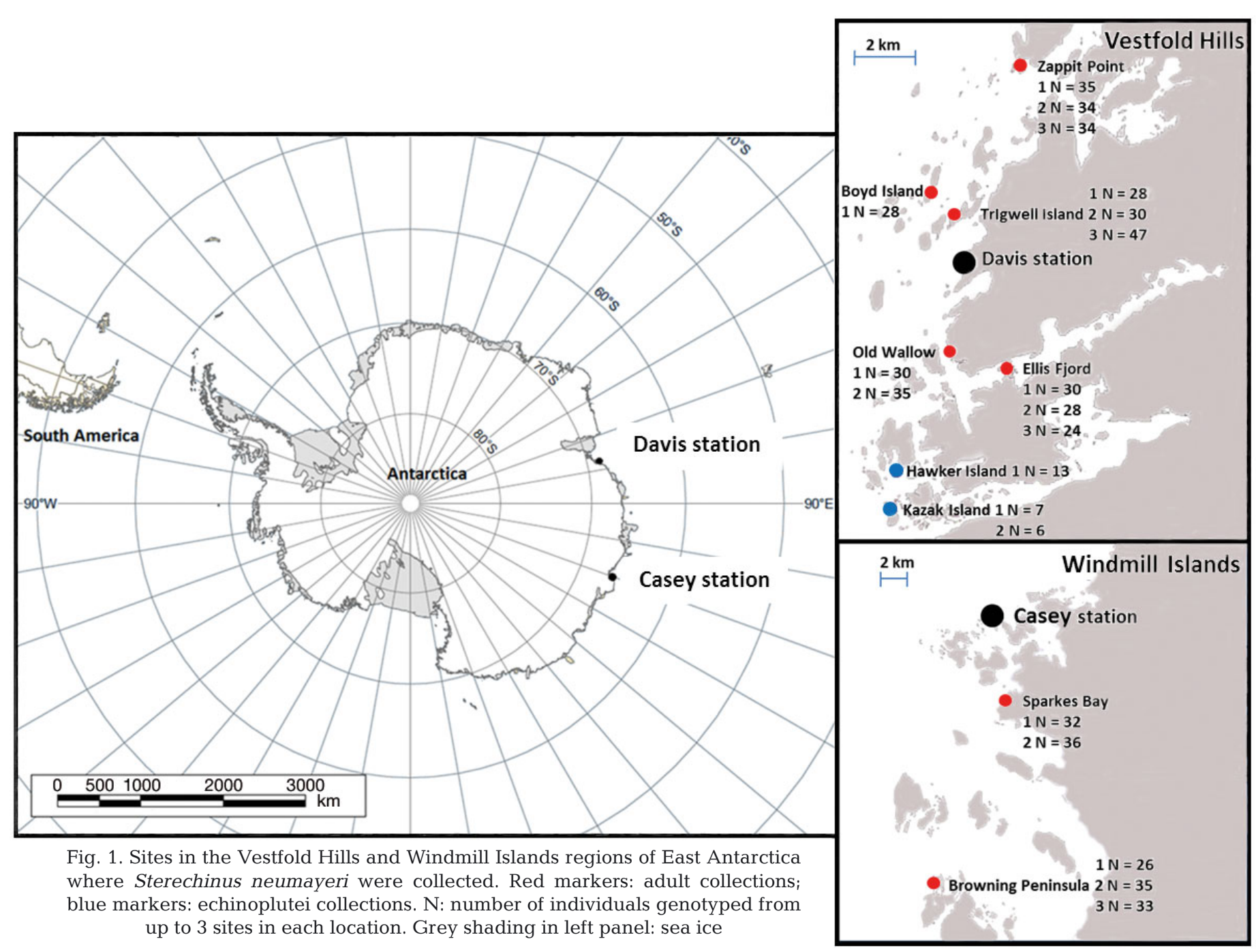

bane) on an Applied Biosystems 3730 DNA Analyzer automated sequencer, using the same primers specified for PCR amplification. Sequence chromatograms were manually inspected to confirm quality, and contiguous sequences were created using MEGA 4.0 (Tamura et al. 2007), aligned using the ClustalW algorithm, and truncated to a consistent length for comparison. The final data comprised $813 \mathrm{bp}$ of CO1 ( $72 \%$ of inter-primer region) and $294 \mathrm{bp}$ of $16 \mathrm{~S}$ (51\% of inter primer region). BLAST searches were performed to confirm that DNA sequence results matched with published sequences of $S$. neumayeri.

Regional-level and fine-scale genetic structure in $S$. neumayeri adults and larvae were assessed using microsatellite DNA markers. Microsatellite loci were developed by Ecogenics GmbH (Zurich, Switzerland) based on 15 individuals utilising the high-throughput genomic sequencing approach (Abdelkrim et al. 2009).
Ten microgrammes of genomic DNA was analysed on a Roche 454 GS-FLX platform (Roche) using a 1/16th run and the GS FLX titanium reagents. A total of 38053 reads, with an average length of 294 bp, were completed. Fragments were screened for microsatellite inserts; a total of 312 suitable candidates were discovered. Primers were designed for 24 of these, which were then tested for polymorphism. Eleven loci were deemed suitable for this study and were amplified in 4 multiplex PCRs (Table S2). PCRs were completed in a total volume of $20 \mu \mathrm{l}$ using Qiagen Multiplex PCR kits containing a final concentration of $3 \mathrm{mM} \mathrm{MgCl}, 100-300 \eta \mathrm{g}$ of template DNA and one unit HotStar Taq DNA Polymerase. Primer concentrations were varied between multiplex reactions to maintain product concentrations within readable limits of the sequencer. Analysis of PCR products was carried out on a CEQ 8000 Genetic Analysis Sys- 
tem (Beckman Coulter) automated sequencer by capillary separation, and alleles were scored as fragment size using CEQ 8000 Genetic Analysis System software (ver. 8.0). Each fragment was visually checked for scoring errors and stutter peaks. Micro-checker 2.2.3 (Van Oosterhout et al. 2004) was used to check for stutter bands and the presence of null alleles. Loci were also tested for linkage disequilibrium in Genepop 4.0.10 (Raymond \& Rousset 1995), with the critical level $\mathrm{p}<0.05$ adjusted for multiple comparisons, using the sequential Bonferroni procedure.

\section{Statistical analysis}

We calculated $F_{\text {ST }}$ and used analysis of molecular variance (AMOVA) in ARLEQUIN 3.5 (Excoffier \& Lischer 2010) to test the hypothesis of no genetic subdivision between regions based on mitochondrial DNA haplotypes. Tests for departures of $F_{\mathrm{ST}}$ from those expected under panmixis (i.e. $F_{\mathrm{ST}}=0$ ) were based on 10000 permutations. Tajima's $D$ statistics were not calculated as they would not have been meaningful given the extremely low variability of the sequence data (see Results).

From the microsatellite genotypes, we calculated measures of genetic diversity including observed heterozygosity $\left(H_{\mathrm{O}}\right)$, expected heterozygosity $\left(H_{\mathrm{E}}\right)$, private alleles $\left(P_{\mathrm{A}}\right)$ and allelic richness $\left(A_{\mathrm{R}}\right)$ for adults from each site using Fstat 2.9.3.2 (Goudet 1995). Permutation tests were performed in Fstat to determine whether the 3 diversity measures were significantly different between the Windmill Islands and Vestfold Hills regions (10000 permutations, 2-tailed p-value). To identify departures from Hardy-Weinberg equilibrium (HWE), exact tests were carried out using Genepop, with 10000 dememorization steps and 500 Markov chains to improve standard error to below the 0.01 threshold. The fixation index $\left(F_{\text {IS }}\right)$ was used to determine the nature of the departures from HWE, where $F_{\text {IS }}>0$ indicates heterozygote deficiencies and $F_{\text {IS }}<0$ indicates heterozygote excess. Significant heterozygote deficiencies were attributed to null alleles by Micro-checker at 8 out of the 11 loci (Stenum 03, 08, 06, 18, 04, 22, 19 and 21), and the Oosterhout correction algorithm was used to generate corrected allele frequencies for subsequent population-level comparisons. Loci were also tested for evidence of selection in Lositan (Antao et al. 2008) using 20000 simulations and the recommended 'neutral mean $F_{\mathrm{ST}}$ ' option (Hemond \& Wilbur 2011). Selection was assessed on the whole adult data set, as well as on the 2 regional data sets separately.
Genetic differentiation among adult populations of $S$. neumayeri was explored using the Stepwise Mutation Model ( $R_{\mathrm{ST}}$; Slatkin $\left.1985 \mathrm{~b}\right)$ and the Infinite Allele Model ( $F_{\mathrm{ST}}$; Kimura \& Crow 1964) using SPAGeDi 1.4 (Hardy \& Vekemans 2002), with 10000 permutations to assess significance. As high within-population variability of microsatellites can reduce the magnitude of $F_{\mathrm{ST}}$ (Hedrick 2005), the standardised measure of differentiation, $F_{\text {ST, }}^{\prime}$ was also calculated in Genalex 6.5 (Peakall \& Smouse 2012). A further measure of differentiation, Jost's $D$, was calculated, as it may be more robust to the high heterozygote frequencies commonly found in microsatellites (Jost 2008, Ryman \& Leimar 2009, Whitlock 2011). Jost's unbiased $D\left(D_{\text {EST }}\right)$ was calculated in R using the package DEMEtics (Gerlach et al. 2010) with 10000 bootstrap resampling steps. To determine which populations were genetically distinct from one another, pairwise $F_{\mathrm{ST}}$ between all sites was calculated in Genalex using 10000 permutations to assess significance.

In order to partition genetic variation among regions, among locations within regions, and among sites within locations, a hierarchical AMOVA was performed in R using the package Hierfstat (Goudet 2005). Boyd Island was excluded from this analysis as there was only one site sampled at this location. For each hierarchical level, 100000 permutations were used to determine significant departures from panmixis.

To determine whether genetic differentiation followed an isolation by distance (IBD) pattern, a correlation between geographic distance and linearised genetic distance was assessed using Mantel tests implemented in Genepop, with 100000 permutations. Distance was represented by the shortest waterbased route between sites; high-resolution data on local ocean currents are unfortunately not available for the area. Mantel tests were performed within regions to determine whether IBD was present at small scales, and across the entire data set to explore IBD at a large scale.

In order to estimate gene flow, the number of migrants per generation $\left(N_{\mathrm{e}} m\right)$ was calculated using private alleles following the method of Slatkin (1985a) in Genepop. To explore migration within and between regions, Geneclass 2 (Piry et al. 2004) was used to detect first generation migrants (F0) present in each site sampled. To account for the possibility of non-sampled source populations, migration detection was calculated using the likelihood method L_home and an exclusion probability of 0.01 (Paetkau et al. 2004). The threshold for probability computa- 
tions was set to 0.05 with 10000 simulated individuals. Individuals identified as F0 migrants were removed from the data set and re-assigned following the frequency-based method of Paetkau et al. (2004) with 100000 simulated individuals and a type 1 error rate of 0.05 .

In order to identify underlying genetic structure, the program STRUCTURE 2.3.3 was used to determine the number of genetic populations within the sample, and whether these populations related to geographical sampling locations (Pritchard et al. 2000, Falush et al. 2003, 2007, Hubisz et al. 2009). Twenty iterations for a $K$-value of $1-20$ were performed with a burn-in period of 50000 and 500000 Markov chain Monte Carlo steps. Likelihood estimates of $K$-values were generated in Structure Harvester (Earl \& vonHoldt 2011) using the delta $K$ method of Evanno et al. (2005).

Measures of genetic diversity and HWE in larval samples were calculated as described for the adult data set. To test for significant differences in diversity measures between larval samples and adult populations from the Vestfold Hills region, permutation tests for $A_{\mathrm{R}}, H_{\mathrm{O}}$ and $H_{\mathrm{E}}$ were implemented in Fstat 2.9.3.2. Genetic differentiation statistics $F_{\mathrm{ST}}, R_{\mathrm{ST}}, F_{\mathrm{ST}}^{\prime}$ and Jost's $D_{\text {EST }}$ were calculated as for adults, both globally and pairwise between samples. We used assignment tests in GeneClass2 to determine the likely population of origin of larvae, assigned as individuals and as sampling groups, using the methods as outlined above for adults. We also assessed the pairwise relatedness among larvae using the Wang estimator in COANCESTRY V1.0.1.8 (Wang 2011), and tested for differences in the relatedness within and among larval samples for any evidence of kin-aggregated dispersal.

\section{RESULTS}

\section{Large-scale patterns of genetic differentiation inferred from mitochondrial DNA}

Across 24 individuals and 2 regions in East Antarctica there were only $2 \mathrm{CO} 1$ haplotypes with a single polymorphic site representing a synonymous substitution. The common CO1 haplotype from both regions (represented by 23 of 24 individuals) has been recorded from the Antarctic Peninsula (GenBank accession HM467227.1) and several locations within the Ross Sea (GenBank accession GU227089.1, KF21457.1). Díaz et al. (2011) reported a total of 21 CO1 haplotypes in Sterechinus neumayeri, including
5 from East Antarctica; however, we were unable to compare these sequences to our own as they are not publically available.

The $16 \mathrm{~S}$ sequences were slightly more variable than CO1, with 4 haplotypes across 24 individuals from both regions, and 3 polymorphic sites. The most common 16S haplotype (represented by 21 of the 24 individuals) has also been recorded from the Antarctic Peninsula (GenBank accession HM467250.1) and the Ross Sea (GenBank accession GU226984.1). Unsurprisingly, there was no significant genetic difference between the Windmill Islands and Vestfold Hills regions based on either the CO1 or the $16 \mathrm{~S}$ sequence data $\left(F_{\mathrm{ST}}=0, \mathrm{p}=1.00\right.$ and $F_{\mathrm{ST}}=0.071, \mathrm{p}=$ 0.483 , respectively). All unique haplotypes generated in this study are available on GenBank (accession MH669388-MH669393).

\section{Genetic diversity and differentiation inferred from microsatellite data}

In total, 545 S. neumayeri adults from East Antarctica were genotyped. There was no evidence of linkage disequilibrium using the default parameters in any of the 11 loci tested. The total number of alleles found at each locus was moderate, ranging from 6 to 19 with an average of 10 alleles per locus (Table S2). Nineteen private alleles were found across all populations. Genetic diversity was not significantly different between regions (for comparisons of $H_{\mathrm{O}}, H_{\mathrm{E}}$ and $A_{\mathrm{R},} \mathrm{p}=0.059, \mathrm{p}=0.162$ and $\mathrm{p}=0.814$, respectively; Table S3).

Populations were largely in HWE, with only 51 of 220 locus-by-site tests showing departures from HWE (Table S4). Departures from HWE were spread over nearly all sites and loci, yet only one site (Trigwell Island 3) showed departures at more than half of the loci tested. After Bonferroni correction, 42 comparisons remained significant, and of these, the vast majority (40) represented heterozygote deficits. These were largely attributed to the presence of null alleles and the data were adjusted accordingly prior to further analysis.

In contrast to results from mitochondrial DNA analysis, we found significant genetic differentiation in adult $S$. neumayeri among sites based on microsatellite data $\left(F_{\mathrm{ST}}=0.010, R_{\mathrm{ST}}=0.016, D_{\mathrm{EST}}=0.025\right.$, $F_{\text {ST }}^{\prime}=0.024 ; \mathrm{p}<0.001$ for all; Table 1). There was no evidence of selection acting on any of the loci when the entire data set was tested, yet balancing selection was detected at Stenum 13 and Stenum 15 (at a significance level of $p<0.01$ ) within the Vestfold Hills 
Table 1. Genetic differentiation at each of 11 microsatellite loci among all adult populations of the Antarctic echinoid Sterechinus neumayeri. These results are from the data set after adjusting for null alleles. Negative values are converted to 0 . Significance: ${ }^{*} p \leq 0.05,{ }^{* *} p \leq 0.01,{ }^{* * *} p \leq 0.001$. $F_{\mathrm{ST}}$ : differentiation based on the Infinite Allele model $R_{\mathrm{ST}}$ : differentiation based on the Stepwise Mutation Model; $D_{\text {EST }}$ : Jost's unbiased $D_{i} F_{\mathrm{ST}}^{\prime}$ : standardised measure of differentiation

\begin{tabular}{|lllll|}
\hline Locus & $F_{\mathrm{ST}}$ & $R_{\mathrm{ST}}$ & $D_{\mathrm{EST}}$ & $F_{\mathrm{ST}}^{\prime}$ \\
\hline Stenum 03 & $0.013^{* * *}$ & 0.002 & $0.046^{* * *}$ & $0.052^{* *}$ \\
Stenum 08 & 0.004 & $0.033^{* * *}$ & 0.008 & 0.011 \\
Stenum 11 & 0.007 & $0.014^{*}$ & 0.001 & 0.006 \\
Stenum 06 & 0.006 & 0.005 & 0.035 & 0.024 \\
Stenum 13 & 0.005 & 0.009 & 0.006 & 0.011 \\
Stenum 18 & $0.020^{* * *}$ & $0.021^{* *}$ & $0.033^{* * *}$ & $0.050^{* * *}$ \\
Stenum 04 & $0.007^{* *}$ & $0.016^{*}$ & $0.068^{* *}$ & $0.034^{* * *}$ \\
Stenum 15 & 0 & 0 & 0 & 0 \\
Stenum 22 & $0.008^{*}$ & $0.016^{*}$ & $0.015^{*}$ & $0.013^{*}$ \\
Stenum 19 & $0.017^{* * *}$ & $0.023^{* *}$ & $0.046^{* * *}$ & $0.055^{* * *}$ \\
Stenum 21 & $0.018^{* * *}$ & 0.014 & $0.016^{* * *}$ & $0.022^{* * *}$ \\
Total & $0.010^{* * *}$ & $0.016^{* * *}$ & $0.025^{* * *}$ & $0.024^{* * *}$ \\
\hline
\end{tabular}

region alone. Hierarchical AMOVA revealed that differentiation was not significant between the 2 regions $\left(F_{\mathrm{ST}}=0.005, \mathrm{p}=0.169\right)$ nor among locations within regions $\left(F_{\mathrm{ST}}=0, \mathrm{p}=0.470\right)$, but was significant among sites within locations $\left(F_{\mathrm{ST}}=0.008, \mathrm{p}<0.001\right)$, i.e. the smallest spatial scale (Table S7). This result was the same whether the raw data set or the data set adjusted for null alleles was tested. However, given that there were only 2 regions at the highest level, the lack of significant differences between regions may be linked to low statistical power, and should be interpreted with caution. There was no isolation by distance among locations across the entire data set $\left(R^{2}=0.304, p=0.071\right)$, nor among sites within each region (Windmill Islands $R^{2}=0.062, p=0.596$; Vestfold Hills $R^{2}=0.023 ; p=0.825$ ). The absence of largescale population structure within the entire data set was also evident in the STRUCTURE analysis, which indicated $K=1$ as the most likely number of populations (based on log likelihood values) and $K=2$ based on delta $K$ (noting the Evanno method cannot resolve $K=1$ ). However, there was no relationship between population structure and geographic location, with all populations showing genetic admixture (Fig. S1).

Within regions, pairwise population estimates of $F_{\text {ST }}$ showed that $80 \%$ of sites within the Windmill Islands, and only $30 \%$ of sites in the Vestfold Hills, were significantly differentiated (Table S5). This pattern was also evident when comparing pairwise $D_{\mathrm{EST}}$ values (Table S5). Values of $F_{\mathrm{ST}}$ and $D_{\mathrm{EST}}$ were generally higher among sites in the Windmill Islands than among sites in the Vestfold Hills, yet values for both regions were considered equally significant (Windmill Islands: $F_{\mathrm{ST}}=0.013, D_{\mathrm{EST}}=0.019, \mathrm{p}<0.001$; Vestfold Hills: $F_{\mathrm{ST}}=0.005, D_{\mathrm{EST}}=0.009, \mathrm{p}<0.001$ ). When the 2 loci suspected to be under balancing selection were removed from the data set, values were more similar within the 2 regions (Windmill Islands: $F_{\mathrm{ST}}=0.009, D_{\mathrm{EST}}=0.018, \mathrm{p}<0.001$; Vestfold Hills: $\left.F_{\mathrm{ST}}=0.007, D_{\mathrm{EST}}=0.012, \mathrm{p}<0.001\right)$.

\section{Gene flow in $S$. neumayeri}

Gene flow in $S$. neumayeri appears limited. Between 72 and $88 \%$ of individuals were assigned to their natal populations (Table 2) although the overall $N_{\mathrm{e}} m$ of 6.1 calculated from private alleles suggests sufficient gene flow to reduce the effects of inbreeding associated with local recruitment (inbreeding connectivity, $N_{\mathrm{e}} m>1$ ) but not to counteract the divergence of populations through genetic drift (drift connectivity, $N_{\mathrm{e}} m>10$; Lowe \& Allendorf 2010). Within the Vestfold Hills region, $20 \%$ of individuals were identified as first generation migrants, as were $22 \%$ of individuals within the Windmill Islands region (Table 2). The assigned source populations for these migrants indicates that gene flow within the Vestfold Hills region appears to occur more frequently between sites in different locations (separated by moderate distances of 1-25 km) than between sites within locations (at small distances of $0.5-1 \mathrm{~km}$ ), further supporting the hierarchical genetic differentiation results. Only $7.5 \%$ of the total identified migrants at Vestfold Hills were assigned to a source population from the Windmill Islands; however, migrants within the Windmill Islands region were assigned almost exclusively to Vestfold Hills populations (Table 2).

\section{The relationship between larval and adult populations of $S$. neumayeri}

A total of 26 echinoplutei larvae from 3 separate sampling events were genotyped. There was significant genetic differentiation between the 3 larval samples, although sample size was low. Populations from Kazak Island 2 and Hawker Island were significantly differentiated based both on $F_{\mathrm{ST}}$ and $D_{\mathrm{EST}}$, and Kazak Island 1 and 2 (the same site sampled 4 days apart) were significantly differentiated based on $D_{\text {EST }}$ alone (Table 3). Since $D_{\mathrm{EST}}$ is generally considered a superior estimation of genetic differentiation for 
Table 2. Assignment of F0 migrants to source populations of the Antarctic echinoid Sterechinus neumayeri. Values represent percentage of individuals collected from locations, assigned to a source population, and unassigned. Values on the diagonal (in bold) represent the proportion of the population that are not F0 migrants. Italicised values represent first-generation migration between regions. Locations in the Vestfold Hills region are: Old Wallow (OW), Boyd Island (BO), Ellis Fjord (EL), Trigwell Island (TR), and Zappit Point (ZP). Locations in the Windmill Islands region are Browning Peninsula (BP) and Sparkes Bay (SB)

\begin{tabular}{|c|c|c|c|c|c|c|c|c|c|c|c|c|c|c|c|c|}
\hline \multirow{3}{*}{$\begin{array}{l}\text { Location } \\
\text { collected }\end{array}$} & \multicolumn{15}{|c|}{ Assigned origin- } & \multirow{3}{*}{$\begin{array}{c}\text { Not } \\
\text { assigned }\end{array}$} \\
\hline & \multicolumn{11}{|c|}{ —Vestfold Hills Region } & \multicolumn{4}{|c|}{-Windmill Islands Region- } & \\
\hline & OW1 OW2 & BO1 & EL1 & EL2 & EL3 & TR1 & TR2 & TR3 & ZP1 & ZP2 & ZP3 & BP1 & BP2 & BP3 & SB1 SB2 & \\
\hline OW1 & $\mathbf{7 6 . 6 7} 3.33$ & 3.33 & & & & & & & 6.67 & & & & & & & 10 \\
\hline OW2 & 77.14 & 2.86 & & & & & & & & & & & & 2.86 & & 17.14 \\
\hline BO1 & & 82.14 & & & & & & & & & & 3.57 & & & & 14.29 \\
\hline EL1 & & & 73.33 & 33.33 & 3.33 & & & & & 3.33 & & & & & & 16.67 \\
\hline EL2 & & & & $\mathbf{7 8 . 5 7}$ & & & & & & & & & & & & 21.43 \\
\hline EL3 & & 4.17 & & 4.17 & 83.33 & & & & & 4.17 & & & & & 4.17 & 0 \\
\hline TR1 & & & & & 3.57 & 78.57 & & & 3.57 & & 3.57 & & & & & 10.71 \\
\hline TR2 & & & 3.33 & & & & 83.33 & & & & 3.33 & & & & 3.33 & 6.67 \\
\hline TR3 & & & & 2.13 & 2.13 & & & 78.72 & & & & 2.13 & & 2.13 & & 12.77 \\
\hline ZP1 & & & & & & & & & 74.29 & & & & & & & 25.71 \\
\hline $\mathrm{ZP} 2$ & 2.94 & 2.94 & & & & & & & & 82.35 & & & & & & 11.76 \\
\hline ZP3 & & & & & & & & & & & 88.24 & & & & & 11.76 \\
\hline BP1 & & & 3.85 & & & & & & 3.85 & & & $\mathbf{7 6 . 9 2}$ & & & & 15.38 \\
\hline BP2 & 2.86 & & & & 2.86 & & & & 2.86 & & & & 80 & & & 11.43 \\
\hline BP3 & & 2.03 & 3.03 & & & & & & & & & & & 81.82 & & 12.12 \\
\hline SB1 & & 3.13 & & & & & & & 3.13 & & & 3.13 & & & 71.88 & 18.75 \\
\hline SB2 & & 2.78 & 2.78 & 2.78 & 2.78 & & 2.78 & & & & & & & & 77.78 & 8.33 \\
\hline
\end{tabular}

Table 3. Pairwise genetic differentiation (as $F_{\mathrm{ST}}, D_{\mathrm{EST}}$ and $F_{\text {ST }}^{\prime}$ ) between larval cohorts of the Antarctic echinoid Sterechinus neumayeri sampled in 2010 from Hawker Island on 9 February $(\mathrm{n}=13)$, Kazak Island (1) on 4 February $(\mathrm{n}=$ $7)$, and again from Kazak Island $(2)$ on 8 February $(n=6)$. Significance: ${ }^{*} \mathrm{p} \leq 0.05,{ }^{* *} \mathrm{p} \leq 0.01$

\begin{tabular}{|lllll|}
\hline & & \multicolumn{1}{c}{$F_{\mathrm{ST}}$} & \multicolumn{1}{c|}{$D_{\mathrm{EST}}$} & \multicolumn{1}{c|}{$F_{\mathrm{ST}}^{\prime}$} \\
\hline Hawker Island & Kazak Island 1 & 0 & 0 & 0 \\
Hawker Island & Kazak Island 2 & $0.063^{* *}$ & $0.133^{* *}$ & 0.140 \\
Kazak Island 1 & Kazak Island 2 & 0.038 & $0.138^{*}$ & 0.096 \\
\hline
\end{tabular}

polymorphic markers (Gerlach et al. 2010), this temporal differentiation is likely to reflect real differences in larval composition, with $F_{\mathrm{ST}}$ more likely to be affected by low sample size. $F_{\text {ST }}^{\prime}$ values were also generally in accordance with $D_{\text {EST }}$ (Table 3 ).

There were significant genetic differences between the Vestfold Hills larvae and adult populations (AMOVA, $\left.F_{\mathrm{ST}}=0.148, \mathrm{p}=0.001\right)$ and pairwise comparisons indicated that this was the case for all adult-larval comparisons $\left(F_{\mathrm{ST}}=0.080-0.150, \mathrm{p}=\right.$ $0.010 ; D_{\text {EST }}=0.181-0.336, \mathrm{p}=0.010$ ), although the small samples sizes preclude major inference from these results. Genetic diversity was not significantly different between larvae and adults at Vestfold Hills (for comparisons of $H_{\mathrm{E}}, H_{\mathrm{O}}$ and $A_{\mathrm{R}} \mathrm{p}=0.962,0.203$ and 0.364, respectively; diversity values for larvae are provided in Table S6) but observed heterozygosity was higher in larvae than in adults (adults $H_{\mathrm{O}}=$ 0.429 , larvae $\left.H_{\mathrm{O}}=0.467, \mathrm{p}<0.01\right)$. The relatedness among larvae within a single plankton tow (mean = -0.0779 ) was not significantly different to the relatedness among adults within a site $($ mean $=-0.0682$; Fig. S2a).

Of the 26 larvae genotyped, only 14 could be assigned unambiguously to a single population of origin, with 5 originating from Ellis Fjord Site 1, 3 from Trigwell Island Site 1, 3 from Zappit Point Site 1, 2 from Boyd Island and 1 from Zappit Point Site 2 (Table S8). The remaining larvae were assigned with equally high probability (80-90\%) to multiple populations, providing little insight into larval dispersal processes. However, when larvae were assigned as groups (based on plankton tow), the Hawker Island larvae were highly likely (61\%) to have originated from Ellis Fjord Site 1, Kazak Island 1 larvae from Zappit Point Site 1 (99.2\% likelihood), and Kazak Island 2 larvae from Zappit Point Site 2 (99.9\% likelihood). Larvae within a sampling group were also more closely related to each other (mean relatedness $=-0.0673$ ) than to larvae from other groups (mean relatedness $=-0.1434 ;$ Fig. S2b), although notably these relatedness values are negative, indicating larvae are not close kin. 


\section{DISCUSSION}

The Antarctic echinoid Sterechinus neumayeri is characterised by fine-scale population structure. This is unexpected given its planktotrophic development and larval dispersal period of up to $4 \mathrm{mo}$. Sites separated by $<1 \mathrm{~km}$ within both the Windmill Islands and Vestfold Hills regions showed low but highly significant genetic differentiation, and there was evidence that populations are largely self-recruiting. However, despite small-scale heterogeneity (at scales of $<1 \mathrm{~km}$ ), populations from locations within Windmill Islands and Vestfold Hills separated by tens of kilometres showed no significant genetic differentiation, consistent with a pattern of chaotic genetic patchiness (Johnson \& Black 1982). Genetic differentiation found among collections of $S$. neumayeri larvae, and between larvae and adults, is also consistent with models such as chaotic genetic patchiness. We found similar levels of genetic diversity in adults and larvae and no evidence of kin aggregation in larvae, a pattern that would not be expected if sweepstakes reproductive success was leading to chaotic genetic patchiness (Hedgecock \& Pudovkin 2011). This suggests that other mechanisms are driving this patchiness such as collective dispersal of larvae, and pre- or post-settlement selection (Eldon et al. 2016). Genetic similarity across regional scales $(1000 \mathrm{~km})$ based both on microsatellite and mitochondrial DNA data may reflect occasional long-distance larval transport, low levels of drift in isolated populations, and/or historical signatures. The latter is apparent in numerous Antarctic benthic invertebrates and may indicate isolation in glacial refugia during the last glacial maximum, followed by circum-Antarctic recolonisation (see Allcock \& Strugnell 2012, Carrea et al. 2016).

\section{Fine-scale structure despite high dispersal potential}

Despite possessing a long pelagic larval phase, $S$. neumayeri populations are genetically differentiated over small distances $(<1 \mathrm{~km})$ with a high degree of natal retention (up to $88 \%$ ) and no signal of isolation by distance. Similarly, unexpected genetic structure with greater differentiation between neighboring than between distant populations has been found in a wide range of other marine taxa with high dispersal potential (e.g. crab: Cornwell et al. 2016; damselfish: Hogan et al. 2010; lobster: Iacchei et al. 2013; kelp bass: Gosling \& Wilkins 1985, Selkoe et al. 2006, Hogan et al. 2010; marine goby: Selwyn et al. 2016).
The numerous underlying mechanisms proposed for this pattern, however, often lack empirical evidence. Broquet et al. (2013) suggested that the genetic structure of larvae be explored to tease out factors such as sweepstake reproductive success in driving chaotic genetic patchiness. Here, we have provided preliminary evidence that larval cohorts of $S$. neumayeri do not have depressed genetic diversity when compared to adult populations, as might be expected through sweepstakes reproductive success (Li \& Hedgecock 1998), and larval groups do not represent aggregations of kin; both factors providing little support for sweepstakes reproductive success as the driver of the chaotic genetic structure in this species (but noting the limited inference from our small sample size). However, there may be other selective or stochastic processes that occur in late-stage larvae and prior to settlement that we have not been able to examine here, and, notably, different processes may affect larval success among years, which we are unable to test, as we only sampled in a single year. There is generally limited support for sweepstakes reproductive success in studies of temperate echinoids, with similar levels of genetic diversity found among different age classes (e.g. Paracentrotus lividus: Calderon \& Turon 2010, Calderon et al. 2012; Strongylocentrotus purpuratus: Flowers et al. 2002 - all based on juvenile data not larvae), and also in a recent study of larval genetic diversity in green shore crabs (Cornwell et al. 2016).

We have also shown some evidence that larvae of $S$. neumayeri collected at the same location $4 \mathrm{~d}$ apart and at different locations $1 \mathrm{~d}$ apart are genetically differentiated, although sample sizes were small and were from only one reproductive season, limiting strong inference. This suggests that differences in the genetic composition of settling larvae may drive patterns of chaotic genetic patchiness in S. neumayeri, although we cannot completely rule out the role of other mechanisms including pre- or post-settlement selection. The concept of collective dispersal of larvae in the water column has been demonstrated in other marine organisms (lobster: Iacchei et al. 2013; fish: Selwyn et al. 2016; barnacles: Veliz et al. 2006; gastropods: Riquet et al. 2017) and predicted for sea urchins (e.g. Moberg \& Burton 2000), and is hypothesised to reflect spatial and temporal variation in the oceanographic processes that transport larvae (Selkoe et al. 2006). That the larval groups of $S$. neumayeri had similar levels of within-population relatedness to that observed in adult populations, but were more related within their larval group than between larval groups, supports the concept of col- 
lective dispersal of larvae spawned within a population leading to chaotic genetic patchiness.

Inter-annual variation in oceanic currents around Antarctica is well established (White \& Peterson 1996), and inter-annual variability in the recruitment success of $S$. neumayeri has been documented (Brey et al. 1995, Bowden et al. 2009), but the high degree of self-recruitment evident in this study suggests that localised currents may facilitate the retention of larvae in natal populations (see Sponaugle et al. 2002). Furthermore, the fact that the larval populations were genetically differentiated from adults, noting that no adults were sampled in the immediate vicinity of larval collections, is also in keeping with the pattern of local recruitment. It is interesting that the larvae collected from Hawker Island were assigned to Ellis Fjord, the most proximal adult population, although larvae collected at Kazak Island were assigned to Zappit Point, the most distant adult population. Notably, the collection point of larvae in the water column may be very different to the final settlement site after 4 mo in the plankton, and hydrological data at fine spatial scales that might inform our understanding of fine-scale dispersal processes is yet to be generated for nearshore East Antarctica.

Larval behaviour of $S$. neumayeri is poorly understood but may also be important in shaping adult population structure. Larval stages of many fish and some invertebrate species display the ability to detect and respond to environmental gradients, actively influencing dispersal (Kingsford et al. 2002, Paris \& Cowen 2004). A recent study on the echinoid Strongylocentrotus droebachiensis showed that larvae have the ability to control buoyancy and position in the water column based on current speed (Sameoto et al. 2010). The ability to detect and respond to such environmental gradients has not been shown for $S$. neumayeri larvae; however, it may provide a mechanism for cohorts to disperse and settle as a group, leading to the fine-scale structure observed in adults. Of interest is that Bowden et al. (2009) found high densities of $S$. neumayeri larvae $\left(\sim 80\right.$ larvae $\left./ 5 \mathrm{~m}^{3}\right)$ close to the seabed and in November, whereas we sampled at the surface in February and only found $\sim 4$ larvae $/ 5 \mathrm{~m}^{3}$. This suggests that many larvae may actually be retained close to or on the seabed, with only a few larvae dispersing in the water column. These behavioural observations may help explain the high levels of self-recruitment indicated by the adult genetic data, which appears contrary to the inference of dispersal from the assignment of larvae found in the water column to distant populations. The small-scale genetic structure of $S$. neumayeri may also be related to the limited movement and narrow habitat ranges of adults (e.g. Dumont et al. 2006).

\section{Large-scale homogeneity}

In contrast to the fine-scale structure among sites in $S$. neumayeri, populations are not significantly differentiated either at the location or regional scale; indeed, the hierarchical AMOVA showed levels of $F_{\mathrm{ST}}$ at the largest scale to be lower than that at the smallest within-site scale, contrary to expectations under a model of isolation by distance. Microsatellite variation generally reflects contemporary processes (Selkoe \& Toonen 2006), which implies that larval dispersal may be occurring between the Windmill Islands and Vestfold Hills regions. This is counterintuitive given the high degree of natal retention and small-scale structure highlighted above. However, only very low levels of migration (i.e. 1 to 10 migrants per generation) are necessary to prevent differentiation through genetic drift (Mills \& Allendorf 1996) and our assignment tests suggest a small percentage of sea urchins in the Windmill Islands may have originated from the Vestfold Hills. This is in accordance with the direction of the ACC and the 4 mo larval pelagic phase of $S$. neumayeri. In addition, iceberg drift as a surrogate for current flow has shown a potential mechanism for the transport of larvae from the nearshore via re-circulation from the Antarctic Coastal Current out to the ACC (Aoki et al. 2010). This would provide a means of easterly passive transport of larvae at speeds of at least $0.2 \mathrm{~m} \mathrm{~s}^{-1}$ (Hofmann 1985), facilitating the $1400 \mathrm{~km}$ journey between the Vestfold Hills and the Windmill Islands. Contemporary larval dispersal would also explain the genetic similarity among regions revealed in the mitochondrial DNA data.

Equally plausible, however, is that populations in the Vestfold Hills and Windmill Islands are isolated, but there are only low levels of genetic drift or weak selection such that the populations have not diverged. In the absence of contemporary gene flow, the presence of identical mitochondrial haplotypes at the Windmill Islands and Vestfold Hills is likely to represent historical patterns. The observation of low diversity and a dominant, widespread haplotype with one or more closely related, rare haplotypes is a common phenomenon in Antarctic marine benthic invertebrates (see Allcock \& Strugnell 2012). It is thought to reflect founder effects from the wide recolonisation of the Antarctic shelf by these species after their 
extensive population reduction and isolation in icefree refugia during the last glacial maximum (see Thatje et al. 2005). Our results therefore concur with those of studies from the Ross Sea and Antarctic Peninsula (Díaz et al. 2011, González-Wevar et al. 2012) that indicate that $S$. neumayeri recolonised the shelf from glacial refugia to achieve its current circum-Antarctic distribution, and this is similar to patterns found in other echinoids (Carrea et al. 2016).

In summary, our study provides one of the first examples of fine-scale genetic structure in a broadcast-spawning Antarctic benthic invertebrate, and lends support to a growing paradigm shift away from the assumption that the duration of the planktonic larval phase is a direct predictor of gene flow in marine organisms. Based on our results, we propose that, despite the potential for long-distance larval dispersal in $S$. neumayeri, most larvae recruit locally and long-distance dispersal is rare. Genetic similarities at the regional scale reinforce the importance of glacial refugia in shaping modern-day populations. Given the importance of maintaining gene flow in managing marine populations, particularly in Antarctica, a region currently threatened by particularly rapid climate change (IPCC 2001, 2007, Aronson et al. 2011), it is vital that we develop a more complete understanding of the processes governing genetic diversity and gene flow in marine fauna.

Acknowledgements. This study was funded by the Australian Government through an Australian Antarctic Science Grant (AAS 3051). We thank the Australian Antarctic Division for logistical and operational support for the project, and the Casey 08/09 and Davis 09/10 marine teams, especially Jonny Stark, Glenn Johnstone, Chris Gillies, Ben Coombe, Simon Reeves, Patti Virtue, Natalie Moltschaniwskyj and Bianca Sfiligoj. We also thank Adam Smolenski (University of Tasmania) for support with the molecular laboratory analysis.

\section{LITERATURE CITED}

Abdelkrim J, Robertson BC, Stanton JAL, Gemmell NJ (2009) Fast, cost-effective development of speciesspecific microsatellite markers by genomic sequencing. Biotechniques 46:185-192

Addison JA, Hart MW (2004) Analysis of population genetic structure of the green sea urchin (Strongylocentrotus droebachiensis) using microsatellites. Mar Biol 144: 243-251

Allcock AL, Strugnell JM (2012) Southern Ocean diversity: new paradigms from molecular ecology. Trends Ecol Evol 27:520-528

Antao T, Lopes A, Lopes R, Beja-Pereira A, Luikart G (2008) LOSITAN: a workbench to detect molecular adaptation based on a $F_{\mathrm{ST}}$-outlier method. BMC Bioinformatics 9:323

Aoki S, Sasai Y, Sasaki H, Mitsudera H, Williams GD (2010)
The cyclonic circulation in the Australian-Antarctic basin simulated by an eddy-resolving general circulation model. Ocean Dyn 60:743-757

Arango CP, Soler-Membrives A, Miller KJ (2011) Genetic differentiation in the circum-Antarctic sea spider Nymphon australe (Pycnogonida; Nymphonidae). Deep Sea Res II 58:212-219

Arnaud-Haond S, Vonau V, Rouxel C, Bonhomme F, Prou J, Goyard E, Boudry P (2008) Genetic structure at different spatial scales in the pearl oyster (Pinctada margaritifera cumingii) in French Polynesian lagoons: beware of sampling strategy and genetic patchiness. Mar Biol 155: 147-157

Aronson RB, Thatje S, McClintock JB, Hughes KA (2011) Anthropogenic impacts on marine ecosystems in Antarctica. Ann NY Acad Sci 1223:82-107

*Baird HP, Miller KJ, Stark JS (2012) Genetic population structure in the Antarctic benthos: insights from the widespread amphipod, Orchomenella franklini. PLOS ONE 7:e34363

* Banks SC, Piggott MP, Williamson JE, Bové U, Holbrook NJ, Beheregaray LB (2007) Oceanic variability and coastal topography shape genetic structure in a long-dispersing sea urchin. Ecology 88:3055-3064

* Bosch I, Beauchamp KA, Steele ME, Pearse JS (1987) Development, metamorphosis, and seasonal abundance of embryos and larvae of the Antarctic sea urchin Sterechinus neumayeri. Biol Bull 173:126-135

Bowden DA, Clarke A, Peck LS (2009) Seasonal variation in the diversity and abundance of pelagic larvae of Antarctic marine invertebrates. Mar Biol 156:2033-2047

* Brey T, Pearse J, Basch L, McClintock JB, Slattery M (1995) Growth and production of Sterechinus neumayeri (Echinoidea: Echinodermata) in McMurdo Sound, Antarctica. Mar Biol 124:279-292

* Brockington S, Peck LS, Tyler PA (2007) Gametogenesis and gonad mass cycles in the common circumpolar Antarctic echinoid Sterechinus neumayeri. Mar Ecol Prog Ser 330: 139-147

Broquet T, Viard F, Yearsley JM (2013) Genetic drift and collective dispersal can result in chaotic genetic patchiness. Evolution 67:1660-1675

* Byrne M, Ho MA, Koleits L, Price C, and others (2013) Vulnerability of the calcifying larval stage of the Antarctic sea urchin Sterechinus neumayeri to near-future ocean acidification and warming. Glob Chang Biol 19: 2264-2275

Calderón I, Turon X (2010) Temporal genetic variability in the Mediterranean common sea urchin Paracentrotus lividus. Mar Ecol Prog Ser 408:149-159

Calderón I, Pita L, Brusciotti S, Palacín C, Turon X (2012) Time and space: genetic structure of the cohorts of the common sea urchin Paracentrotus lividus in Western Mediterranean. Mar Biol 159:187-197

* Carrea C, Burridge CP, King CK, Miller KJ (2016) Population structure and long-term decline in three species of heart urchins Abatus spp. near-shore in the Vestfold Hills region, East Antarctica. Mar Ecol Prog Ser 545: 227-238

KCornwell BH, Fisher JL, Morgan SG, Neigel JE (2016) Chaotic genetic patchiness without sweepstakes reproduction in the shore crab Hemigrapsus oregonensis. Mar Ecol Prog Ser 548:139-152

Dell RK (1972) Antarctic benthos. In: Russell FS, Yonge M (eds) Advances in marine biology, Vol 10. Academic 
Press, New York, NY, p 1-216

Díaz A, Féral JP, David B, Saucède T, Poulin E (2011) Evolutionary pathways among shallow and deep-sea echinoids of the genus Sterechinus in the Southern Ocean. Deep Sea Res II 58:205-211

Dumont CP, Himmelman JH, Russell MP (2006) Daily movement of the sea urchin Strongylocentrotus droebachiensis in different subtidal habitats in eastern Canada. Mar Ecol Prog Ser 317:87-99

* Duran S, Palacín C, Becerro MA, Turon X, Giribet G (2004) Genetic diversity and population structure of the commercially harvested sea urchin Paracentrotus lividus (Echinodermata, Echinoidea). Mol Ecol 13:3317-3328

* Earl DA, vonHoldt BM (2012) STRUCTURE HARVESTER: a website and program for visualizing STRUCTURE output and implementing the Evanno method. Conserv Genet Resour 4:359-361

Eldon B, Riquet F, Yearsley J, Jollivet D, Broquet T (2016) Current hypotheses to explain genetic chaos under the sea. Curr Zool 62:551-566

Ericson J, Ho M, Miskelly A, King C, Virtue P, Tilbrook B, Byrne M (2012) Combined effects of two ocean change stressors, warming and acidification, on fertilization and early development of the Antarctic echinoid Sterechinus neumayeri. Polar Biol 35:1027-1034

Evanno G, Regnaut S, Goudet J (2005) Detecting the number of clusters of individuals using the software STRUCTURE: a simulation study. Mol Ecol 14:2611-2620

Excoffier L, Lischer HEL (2010) Arlequin suite ver 3.5: a new series of programs to perform population genetics analyses under Linux and Windows. Mol Ecol Resour 10: 564-567

Falush D, Stephens M, Pritchard JK (2003) Inference of population structure using multilocus genotype data: linked loci and correlated allele frequencies. Genetics 164: $1567-1587$

Falush D, Stephens M, Pritchard JK (2007) Inference of population structure using multilocus genotype data: dominant markers and null alleles. Mol Ecol Notes doi: 10.1111/j.1471-8286.2007.01758.x

Faurby S, Barber PH (2012) Theoretical limits to the correlation between pelagic larval duration and population genetic structure. Mol Ecol 21:3419-3432

Féral JP (2002) How useful are the genetic markers in attempts to understand and manage marine biodiversity? J Exp Mar Biol Ecol 268:121-145

Foo SA, Sparks KM, Uthicke S, Karelitz S, Barker M, Byrne M, Lamare M (2016) Contributions of genetic and environmental variance in early development of the Antarctic sea urchin Sterechinus neumayeri in response to increased ocean temperature and acidification. Mar Biol 163:130

Flowers JM, Schroeter SC, Burton RS (2002) The recruitment sweepstakes has many winners: genetic evidence from the sea urchin Strongylocentrotus purpuratus. Evolution 56:1445-1453

Gerlach G, Jueterbock A, Depperman J, Harmand P (2010) Calculations of population differentiation based on GST and D: forget GST but not all of statistics! Mol Ecol 19: 3845-3852

*González-Wevar CA, Diaz A, Gerard K, Cañete JI, Poulin E (2012) Divergence time estimations and contrasting patterns of genetic diversity between Antarctic and southern South America benthic invertebrates. Rev Chil Hist Nat 85:445-456
Gosling EM, Wilkins NP (1985) Genetics of settling cohorts of Mytilus edulis: preliminary observations. Aquaculture 44:115-123

* Goudet J (1995) Fstat version 1.2: a computer program to calculate F-statistics. J Hered 86:485-486

Goudet J (2005) Hierfstat, a package for R to compute and test hierarchical F-statistics. Mol Ecol Notes 5:184-186

*Hardy OJ, Vekemans X (2002) Spagedi: a versatile computer program to analyse spatial genetic structure at the individual or population levels. Mol Ecol Notes 2: $618-620$

* Haye PA, Segovia NI, Muñoz-Herrera NC, Gálvez FE, and others (2014) Phylogeographic structure in benthic marine invertebrates of the southeast Pacific coast of Chile with differing dispersal potential. PLOS ONE 9:e88613

Hedgecock D (1982) Genetic consequences of larval retention: theoretical and methodological aspects. In: Kennedy VS (ed) Estuarine comparisons. Academic Press, New York, NY, p 553-568

Hedgecock D (1994) Does variance in reproductive success limit effective population size of marine organisms? In: Beaumont A (ed) Genetics and evolution of aquatic organisms. Chapman \& Hall, London, p 122-134

*Hedgecock D, Pudovkin AI (2011) Sweepstakes reproductive success in highly fecund marine fish and shellfish: a review and commentary. Bull Mar Sci 87:971-1002

* Hedrick PW (2005) A standardized genetic differentiation measure. Evolution 59:1633-1638

Hemond EM, Wilbur AE (2011) Microsatellite loci indicate population structure and selection between Atlantic and Gulf of Mexico populations of the bay scallop Argopecten irradians. Mar Ecol Prog Ser 423:131-142

*Hess H, Bingham B, Cohen S, Grosberg RK, Jefferson W, Walters L (1988) The scale of genetic differentiation of Leptosynapta clarki (Heding), an infaunal brooding holothuroid. J Exp Mar Biol Ecol 122:187-194

*Hoffman JI, Peck LS, Linse K, Clarke A (2011) Strong population genetic structure in a broadcast-spawning antarctic marine invertebrate. J Hered 102:55-66

炎Hoffman JI, Clarke A, Clark MS, Fretwell P, Peck LS (2012) Unexpected fine-scale population structure in a broadcast-spawning antarctic marine mollusc. PLOS ONE 7: e32415. doi:32410.31371/journal.pone.0032415

*Hofmann EE (1985) The large-scale horizontal structure of the Antarctic Circumpolar Current from FGGE drifters. J Geophys Res 90:7080-7097

* Hogan JD, Thiessen RJ, Heath DD (2010) Variability in connectivity indicated by chaotic genetic patchiness within and among populations of a marine fish. Mar Ecol Prog Ser 417:263-275

Hubisz MJ, Falush D, Stephens M, Pritchard JK (2009) Inferring weak population structure with the assistance of sample group information. Mol Ecol Resour 9:1322-1332

*Hunt A (1993) Effects of contrasting patterns of larval dispersal on the genetic connectedness of local populations of two intertidal starfish, Patiriella calcar and P. exigua. Mar Ecol Prog Ser 92:179-186

*Hunter RL, Halanych KM (2008) Evaluating connectivity in the brooding brittle star Astrotoma agassizii across the Drake Passage in the Southern Ocean. J Hered 99: $137-148$

*Hunter RL, Halanych KM (2010) Phylogeography of the Antarctic planktotrophic brittle star Ophionotus victoriae reveals genetic structure inconsistent with early life history. Mar Biol 157:1693-1704 
Iacchei M, Ben-Horin T, Selkoe KA, Bird CE, GarciaRodriguez FJ, Toonen RJ (2013) Combined analyses of kinship and FST suggest potential drivers of chaotic genetic patchiness in high gene-flow populations. Mol Ecol 22:3476-3494

IPCC (2001) Synthesis report. A contribution of working groups I, II and III to the third assessment report of the Intergovernmental Panel on Climate Change. Cambridge University Press, Cambridge

IPCC (2007) The fourth assessment report of the Intergovernmental Panel on Climate Change. Cambridge University Press, Cambridge

Iuri V, Patti FP, Procaccini G (2007) Phylogeography of the sea urchin Paracentrotus lividus (Lamarck) (Echinodermata: Echinoidea): first insights from the South Tyrrhenian Sea. Dev Hydrobiol 193:77-84

Johnson MS, Black R (1982) Chaotic genetic patchiness in an intertidal limpet, Siphonaria sp. Mar Biol 70:157-164

Johnson MS, Holborn K, Black R (1993) Fine-scale genetic patchiness and genetic heterogeneity of recruits of the corallivorous gastropod Drupella cornus. Mar Biol 117:91-96

Jost L (2008) $G_{\mathrm{ST}}$ and its relatives do not measure differentiation. Mol Ecol 17:4015-4026

Kelly RP, Palumbi SR (2010) Genetic structure among 50 species of the northeastern pacific rocky intertidal community. PLOS ONE 5:e8594

Kimura M, Crow J (1964) The number of alleles that can be maintained in a finite population. Genetics 49:725-738

King CK, Riddle MJ (2001) Effects of metal contaminants on the development of the common Antarctic sea urchin Sterechinus neumayeri and comparisons of sensitivity with tropical and temperate echinoids. Mar Ecol Prog Ser 215:143-154

Kingsford MJ, Leis JM, Shanks AL, Lindeman KC, Morgan SG, Pineda J (2002) Sensory environments, larval abilities and local self-recruitment. Bull Mar Sci 70:309-340

Larson RJ, Julian RM (1999) Spatial and temporal genetic patchiness in marine populations and their implications for fisheries management. CCOFI Rep 40:94-99

Kedoux JB, Tarnowska K, Gérard K, Lhuillier E and others (2012) Fine-scale spatial genetic structure in the brooding sea urchin Abatus cordatus suggests vulnerability of the Southern Ocean marine invertebrates facing global change. Polar Biol 35:611-623

Lessios HA, Kessing D, Robertson R, Oaulay G (1999) Phylogeography of the pantropical sea urchin Eucidaris in relation to land barriers and ocean currents. Evolution 53:806-817

Lessios HA, Kessing D, Pearse S (2001) Population structure and speciation in tropical seas: global phylogeography of the sea urchin Diadema. Evolution 55:955-975

Li G, Hedgecock D (1998) Genetic heterogeneity, detected by PCR-SSCP, among samples of larval Pacific oysters (Crassostrea gigas) supports the hypothesis of large variance in reproductive success. Can J Fish Aquat Sci 55: 1025-1033

Lister KN, Lamare MD, Burritt DJ (2010) Sea ice protects the embryos of the Antarctic sea urchin Sterechinus neumayeri from oxidative damage due to naturally enhanced levels of UV-B radiation. J Exp Biol 213: 1967-1975

Lister KN, Lamare MD, Burritt DJ (2015) Pollutant resilience in embryos of the Antarctic sea urchin Sterechinus neumayeri reflects maternal antioxidant status. Aquat Toxicol 161:61-72
Lowe WH, Allendorf FW (2010) What can genetics tell us about population connectivity? Mol Ecol 19:3038-3051

Maltagliati F, Di Giuseppe G, Barbieri M, Castelli A, Dini F (2010) Phylogeography and genetic structure of the edible sea urchin Paracentrotus lividus (Echinodermata: Echinoidea) inferred from the mitochondrial cytochrome b gene. Biol J Linn Soc 100:910-923

* McCartney MA, Keller G, Lessios HA (2000) Dispersal barriers in tropical oceans and speciation in Atlantic and eastern Pacific sea urchins of the genus Echinometra. Mol Ecol 9:1391-1400

*Miller KJ, Ayre DJ (2008) Population structure is not a simple function of reproductive mode and larval type: insights from tropical corals. J Anim Ecol 77:713-724

Miller KJ, Maynard BT, Mundy CN (2009) Genetic diversity and gene flow in collapsed and healthy abalone fisheries. Mol Ecol 18:200-211

Mills LS, Allendorf FW (1996) The one-migrant-per-generation rule in conservation and management. Conserv Biol 10:1509-1518

Moberg PE, Burton RS (2000) Genetic heterogeneity among adult and recruit red sea urchins, Strongylocentrotus franciscanus. Mar Biol 136:773-784

Ni L, Li Q, Kong L (2011) Microsatellites reveal fine-scale genetic structure of the Chinese surf clam Mactra chinensis (Mollusca, Bivalvia, Mactridae) in Northern China. Mar Ecol 32:488-497

Nowlin WD, Klinck JM (1986) The physics of the Antarctic Circumpolar Current. Rev Geophys 24:469-491

* Paetkau D, Slade R, Burden M, Estoup A (2004) Direct real-time estimation of migration rate using assignment methods: a simulation based exploration of accuracy and power. Mol Ecol 13:55-65

* Palsbøll PJ, Be'rube M, Allendorf FW (2007) Identification of management units using population genetic data. Trends Ecol Evol 22:11-16

Palumbi SR (1994) Genetic divergence, reproductive isolation and marine speciation. Annu Rev Ecol Syst 25: $547-572$

*Palumbi SR (2003) Population genetics, demographic connectivity, and the design of marine reserves. Ecol Appl 13:S146-S158

* Paris CB, Cowen RK (2004) Direct evidence of a biophysical retention mechanism for coral reef fish larvae. Limnol Oceanogr 49:1964-1979

Peakall R, Smouse PE (2012) GenAlEx 6.5: genetic analysis in Excel. Population genetic software for teaching and research-an update. Bioinformatics 28:2537-2539

* Pearse J, McClintock JB, Bosch I (1991) Reproduction of antarctic benthic marine invertebrates: tempos, modes, and timing. Am Zool 31:65-80

Peck LS (2005) Prospects for survival in the Southern Ocean: vulnerability of benthic species to temperature change. Antarct Sci 17:497-507

*ैPenant G, Aurelle D, Feral JP, Chenuil A (2013) Planktonic larvae do not ensure gene flow in the edible sea urchin Paracentrotus lividus. Mar Ecol Prog Ser 480:155-170

* Piry S, Alapetite A, Cornuet JM, Paetkau D, Baudouin L, Estoup A (2004) GeneClass2: a software for genetic assignment and first-generation migrant detection. J Hered 95:536-539

* Pritchard JK, Stephens M, Donnelly P (2000) Inference of population structure using multilocus genotype data. Genetics 155:945-959

Kaymond M, Rousset F (1995) GENEPOP (version 1.2): pop- 
ulation genetics software for exact tests and ecumenicism. J Hered 86:248-249

Reeb CA, Avise JC (1990) A genetic discontinuity in a continuosly distributed species: mitochondrial DNA in the American oyster Crassostrea virginica. Genetics 124: 397-406

Riquet F, Comtet T, Broquet T, Viard F (2017) Unexpected collective larval dispersal but little support for sweepstakes reproductive success in the highly dispersive brooding mollusc Crepidula fornicata. Mol Ecol 26: 5467-5483

Roberts CM (1997) Connectivity and management of caribbean coral reefs. Science 278:1454-1457

Ryman N, Leimar O (2009) GST is still a useful measure of genetic differentiation - a comment on Jost's D. Mol Ecol 18:2084-2087

Sá-Pinto A, Branco MS, Alexandrino PB, Fontaine MC, Baird SJE (2012) Barriers to gene flow in the marine environment: insights from two common intertidal limpet species of the Atlantic and Mediterranean. PLOS ONE 7: e50330

Sahade R, Tatian M, Kowalke J, Kuhne S, Esnal GB (1998) Benthic faunal associations on soft substrates at Potter Cove, King George Island, Antarctica. Polar Biol 19:85-91

Sameoto JA, Ross T, Metaxas A (2010) The effect of flow on larval vertical distribution of the sea urchin, Strongylocentrotus droebachiensis. J Exp Mar Biol Ecol 383: 156-163

Selkoe KA, Toonen RJ (2006) Microsatellites for ecologists: a practical guide to using and evaluating microsatellite markers. Ecol Lett 9:615-629

Selkoe KA, Gaines SD, Caselle JE, Warner RR (2006) Current shifts and kin aggregation explain genetic patchiness in fish recruits. Ecology 87:3082-3094

Selwyn JD, Hogan JD, Downey-Wall AM, Gurski LM, Portnoy DS, Heath DD (2016) Kin-aggregations explain Chaotic Genetic Patchiness, a commonly observed genetic pattern, in a marine fish. PLOS ONE 11: e0153381

Slatkin M (1985a) Rare alleles as indicators of gene flow. Evolution 39:53-65

Slatkin M (1985b) Gene flow in natural populations. Annu Rev Ecol Syst 16:393-430

Sponaugle S, Cowen RK, Shanks A, Morgan SG and others (2002) Predicting self-recruitment in marine populations: biophysical correlates and mechanisms. Bull Mar Sci 70: 341-375

Tamura K, Dudley J, Nei M, Kumar S (2007) MEGA4: Molecular Evolutionary Genetics Analysis (MEGA) soft-

Editorial responsibility: Philippe Borsa, Montpellier, France ware version 4.0. Molecular Biology and Evolution 24: 1596-1599

Taylor MS, Hellberg ME (2003) Genetic evidence for local retention of pelagic larvae in a Caribbean reef fish. Science 299:107-109

Teske PR, Papadopoulos I, Zardi GI, McQuaid CD, Edkins MT, Griffiths CL, Barker NP (2007) Implications of life history for genetic structure and migration rates of southern African coastal invertebrates: planktonic, abbreviated and direct development. Mar Biol 152:697-711

Thatje S, Hillenbrand CD, Larter R (2005) On the origin of Antarctic marine benthic community structure. Trends Ecol Evol 20:534-540

*Thornhill DJ, Mahon AR, Norenburg JI, Halanych KM (2008) Open-ocean barriers to dispersal: a test case with the Antarctic Polar Front and the ribbon worm Parborlasia corrugatus (Nemertea: Lineidae). Mol Ecol 17: 5104-5117

* Underwood JN, Smith LD, van Oppen MJ, Gilmour JP (2009) Ecologically relevant dispersal of corals on isolated reefs: implications for managing resilience. Ecol Appl 19:18-29

*Van Oosterhout C, Hutchinson WF, Wills DPM, Shipley P (2004) Micro-checker: software for identifying and correcting genotyping errors in microsatellite data. Mol Ecol Notes 4:535-538

Veliz D, Duchesne P, Bourget E, Bernatchez L (2006) Genetic evidence for kin aggregation in the intertidal acorn barnacle (Semibalanus balanoides). Mol Ecol 15: 4193-4202

*Wang J (2011) COANCESTRY: a program for simulating, estimating and analysing relatedness and inbreeding coefficients. Mol Ecol Resour 11:141-145

Waters JM, Roy MS (2004) Phylogeography of a high-dispersal New Zealand sea-star: does upwelling block geneflow? Mol Ecol 13:2797-2806

WWeber AAT, Mérigot B, Valière S, Chenuil A (2015) Influence of the larval phase on connectivity: strong differences in the genetic structure of brooders and broadcasters in the Ophioderma longicauda species complex. Mol Ecol 24:6080-6094

White WB, Peterson RG (1996) An Antarctic circumpolar wave in surface pressure, wind, temperature and sea-ice extent. Nature 380:699-702

Whitlock MC (2011) $G_{\mathrm{ST}}^{\prime}$ and $D$ do not replace $F_{\mathrm{ST}}$. Mol Ecol 20:1083-1091

*Yasuda N, Nagai S, Hamaguchi M, Okaji K, Gérard K, Nadaoka K (2009) Gene flow of Acanthaster planci (L.) in relation to ocean currents revealed by microsatellite analysis. Mol Ecol 18:1574-1590

Submitted: February 20, 2017; Accepted: May 23, 2018, Proofs received from author(s): July 26, 2018 